\title{
AKTIVITAS ANTIOKSIDAN DAN KARAKTERISTIK CUKA BUAH MANGROVE PEDADA (Sonneratia alba)
}

\author{
Hardoko $^{\text {a,* }}$, Nur Hasyim Prihanto ${ }^{\text {a }}$, Bambang Budi Sasmito ${ }^{\text {a }}$ \\ ${ }^{a}$ Program Studi Teknologi Hasil Perikanan, Jl. Veteran No. 1 Malang 65145, Indonesia \\ *Koresponden penulis : hardoko@ub.ac.id
}

\begin{abstract}
Abstrak
Cuka buah dibuat dari buah yang difermentasi menggunakan mikroba yang digunakan untuk membuat cuka. Sifat fungsional cuka buah ditentukan oleh jenis buah, jumlah gula, dan lama fermentasi yang dilakukan. Tujuan penelitian ini adalah untuk mengetahui jumlah gula yang ditambahkan dan lama fermentasi yang dilakukan terhadap aktivitas antioksidan cuka buah mangrove pedada. Metode penelitian yang digunakan adalah eksperimen penambahan gula $(22,5 \%, 25 \%, 27,5 \%, 30 \%)$ dan lama fermentasi $(5,7$, dan 9 hari). Hasilnya menunjukkan bahwa makin tinggi jumlah gula yang ditambahkan cenderung meningkatkan aktivitas antioksidan, tetapi lama fermentasi yang dilakukan dapat meningkatkan aktivitas antioksidan hanya sampai pada lama fermentasi 7 hari dan kemudian aktivitas antioksidan menurun setelah lama fermentasi 7 hari. Hasil perlakuan terbaik didapatkan pada lama fermentasi hari ke-7 dan penambahan gula $25 \%$ dengan nilai aktivitas antioksidan $\mathrm{IC}_{50} 48,04 \mathrm{ppm}$, asam asetat 8,17\%, pH 3,13, total fenol 91,3 mgGAE/100g, dan vitamin C 104,3 mg/100g.
\end{abstract}

Kata kunci : aktivitas antioksidan, cuka buah, mangrove pedada, gula, lama fermentasi

\begin{abstract}
Fruit vinegar is made from fermented fruits using microbes used to make vinegar. The functional properties of fruit vinegar are determined by the type of fruit, the amount of sugar, and the length of fermentation carried out. The purpose of this study was to determine the amount of sugar added and the length of fermentation carried out on the antioxidant activity of pedada mangrove fruit vinegar. The research method used was an experiment of adding sugar (22.5\%, 25\%, 27.5\%, 30\%) and fermentation time (5, 7 and 9 days). The results showed that the higher the amount of sugar added tended to increase antioxidant activity, but the length of fermentation carried out could increase antioxidant activity only up to 7 days of fermentation and then antioxidant activity decreased after 7 days of fermentation. The best treatment results were obtained at the 7 th day of fermentation and $25 \%$ sugar addition with the value of antioxidant activity $I C_{50} 48.04$ ppm, acetic acid $8.17 \%$, pH 3.13, total phenol $91.3 \mathrm{mgGAE} / 100 \mathrm{~g}$, and vitamin C $104.3 \mathrm{mg} / 100 \mathrm{~g}$.
\end{abstract}

Keywords: antioxidant activity, fermentation time, fruit vinegar, pedada mangrove, sugar

\section{PENDAHULUAN}

Tumbuhan mangrove di Indonesia merupakan yang terbanyak di dunia, baik dari segi kuantitas area $\left( \pm 42.550 \mathrm{~km}^{2}\right)$ maupun jumlah spesies $( \pm 45$ spesies $)$. Mangrove memiliki banyak manfaat yang bersinggungan langsung dengan kehidupan manusia, mulai dari manfaat ekologi sampai dengan manfaat sebagai sumber pangan dan obat. Maka potensi perlu digali sehingga dapat dimanfaatkan semaksimal mungkin demi kepentingan bersama [1].

Mangrove Sonneratia atau lebih dikenal dengan nama daerah pedada atau bogem, adalah jenis mangrove yang dapat dimakan buahnya [2]. Buah pedada merupakan buah yang bagian dasarnya terbungkus kelopak bunga, berbentuk bola, 
dan ujung buah tersebut bertangkai. Buah tersebut tidak beracun dan langsung dapat dimakan. Buah pedada memiliki rasa yang asam dan aroma yang khas yang menjadi daya tarik buah tersebut [3].

Buah S. alba memiliki kandungan senyawa alkaloid, flavonoid, fenolik, tannin, dan steroid [4]. Sonneratia alba merupakan salah satu jenis mangrove yang tidak beracun, tidak memerlukan penanganan khusus dan langsung dapat dimakan. Buah muda berasa asam dan memiliki kandungan bioaktif yang tinggi yang secara khusus dapat dimanfaatkan sebagai antioksidan.

Buah pedada sering disebut juga apel mangrove, karena bentuknya yang mirip buah apel. Buah apel selain dikonsumsi segar sering diolah menjadi cuka apel yang bermanfaat untuk kesehatan. Kandungan gizi dan bioaktif buah pedada lebih tinggi dan lebih variatif dibandingkan buah apel. Dengan demikian apabila buah pedada difermentasi menjadi cuka buah berpotensi fungsional lebih baik daripada cuka apel. Proses pembuatan cuka melalui proses fermentasi alkohol dan fermentasi asetat yang dapat diperoleh dari bahan kaya gula seperti anggur, apel, malt, gula, dan sebagainya [5].

Berdasarkan penjelasan diatas, maka perlu dilakukan penelitian yang bertujuan untuk pengembangan produk cuka buah mangrove Sonneratia alba yang berkarakteristik sesuai SNI dan mengandung antioksidan tinggi.

\section{BAHAN DAN METODE}

\section{Bahan dan Alat}

Bahan yang digunakan dalam pembuatan cuka mangrove adalah buah mangrove jenis Sonneratia alba (pedada) masak dengan ciri apabila dikupas maka dalamnya berwana merah keungu-unguan yang didapat dari daerah pesisir Sumenep, gula pasir, air, plastisin, plastik wrap (Total wrap $30 \mathrm{~cm}$ x $500 \mathrm{~m}$ ), alumunium foil (Heavy Duty 7,6 m x $450 \mathrm{ml}$ ), spirtus (Mulia Chemical $500 \mathrm{ml}$ ), kertas saring whatman, saccharomyses cerevisiae dan Acetobacter aceti. Bahan yang digunakan dalam analisis kimia antara lain Natrium Hidroksida $(\mathrm{NaOH})$
$0,1 \mathrm{~N}$, indikator PP $1 \%$, DPPH $0,2 \mathrm{M}$, folin ceiocalteu $\left(\mathrm{H}_{3} \mathrm{PO}_{4}\left(\mathrm{M}_{0} \mathrm{O}_{3}\right)_{12}\right) 50 \%$, asam galat $\left(\mathrm{C}_{7} \mathrm{H}_{6} \mathrm{O}_{5}\right)$, Natrium Karbonat $\left(\mathrm{Na}_{2} \mathrm{CO}_{3}\right) 2 \%$, methanol $\left(\mathrm{CH}_{3} \mathrm{OH}\right)$ dan aquades $\left(\mathrm{H}_{2} \mathrm{O}\right)$.

Alat yang digunakan dalam proses pengolahan cuka adalah baskom untuk tempat mencuci buah pedada, panci berbahan steinless steel untuk merebus buah pedada, botol sebagai tempat fermentasi sari buah, pisau untuk mengupas kulit buah pedada, saringan, corong plastik, sendok, selang, aerator (Amara AA-350), blander (Nastional Nice MX-T2GN) untuk menghancurkan buah pedada dan timbangan (Camry EK505). Alat yang digunakan untuk analisis kimia antara lain tabung reaksi (pyrex), bunsen, buret, Erlenmeyer (pyrex), inkubator, gelas ukur (pyrex), timbangan digital (Camry EK505), kompor (Maspion S300), $\mathrm{pH}$ meter, pipet volume (pyrex), pipet tetes (pyrex), vortex (pyrex), spektrofotometer (WTW SpectroFlex 6600), beaker glass (pyrex), bola hisap, botol gelap, mikro pipet (TopPette Nescco), inkubator, dan Vortex mixer (Velp ZX3).

\section{Metode Penelitian}

Metode penelitian yang digunakan adalah metode eksperimen penambahan jumlah gula $(10 \%, 15 \%, 20 \%$, dan $25 \%)$ dan lama fermentasi (5 hari, 7 hari dan 9 hari) pada fermentasi buah cuka buah pedada. Perlakuan percobaan ini didasarkan pada pembuatan cuka murbei [6].

\section{Pembuatan Sari Buah Mangrove dan Fermentasi}

Pembuatan sari buah mangove pedada melalui tahapan sortasi dan trimming, pengupasan, pencucian, blanching, tempering, penambahan air $1: 1$, penghancuran dengan blender, dan penyaringan sehingga diperoleh sari buah manrove pedada. Sortasi dilakukan berdasarkan karakter fisiknya, seperti ukuran, bentuk dan warna. Trimming ini dilakukan dengan memisahkan buah pedada dari tangkainya. Pengupasan kulit buah pedada dilakukan menggunakan pisau yang terbuat dari stainless steel hingga kulitnya bersih. Pencucian dilakukan untuk menghilangkan kotoran dan getah kulit yang masih menempel pada daging buah mangrove. Blanching 
dengan air mendidih bertujuan untuk melunakkan jaringan bahan, menonaktifkan enzim dalam buah, serta menurunkan jumlah mikroba yang ada pada buah pedada. Perebusan ini dilakukan selama 10 menit [7]. Tempering (pendinginan) dilakukan hingga suhu mencapai $\pm 27^{\circ} \mathrm{C}$ dengan cara didiamkan di suhu ruang. Penghancuran ini dilakukan dengan menggunakan blender dengan menambahkan air 1:1 sehingga diperoleh bubur buah pedada. Penyaringan dilakukan untuk memeperoleh sari buah yang jernih dari bubur pedada.

Sari buah mangrove Sonneratia alba dilakukan proses fermentasi menggunakan bakteri S. cereviceae dan Acetobacter aceti dengan formulasi bahan seperti Tabel 1. Tahapan proses fermentasi melalui tahap penambahan gula, pengaturan $\mathrm{pH} 4,5$, penambahan Saccharomyces cerevisiae sebanyak 5\% dan Acetobacter aceti sebanyak 7\%. Proses fermentasi dilakukan pada suhu $30^{\circ} \mathrm{C}$ dalam inkubator selama 5 hari, 7 hari dan 9 hari [6]. Hasil fermentasi dipanaskan untuk menghentikan proses dan disaring sehingga diperoleh cuka buah pedada yang siap untuk dianalisis.

Tabel 1. Formulasi cuka buah mangrove pedada (Sonneratia alba) (modifikasi [6])

\begin{tabular}{lcccl}
\hline \multirow{2}{*}{ Formulasi } & \multicolumn{4}{c}{ Perlakuan } \\
\cline { 2 - 5 } & $\begin{array}{c}\text { M1 } \\
(\mathbf{2 2 , 5 \% )}\end{array}$ & $\begin{array}{c}\text { M2 } \\
\mathbf{( 2 5 \% )}\end{array}$ & $\begin{array}{c}\text { M3 } \\
\mathbf{( 2 7 , 5 \% )}\end{array}$ & $\begin{array}{l}\text { M4 } \\
\mathbf{( 3 0 \% )}\end{array}$ \\
\hline $\begin{array}{c}\text { Sari buah } \\
(\mathrm{ml})\end{array}$ & 250 & 250 & 250 & 250 \\
Gula (g) & 18,75 & 25 & 31,25 & 37,5 \\
$\begin{array}{c}\text { S.cerevicea } \\
\text { Acetobacter } \\
\text { aceti }^{*}\end{array}$ & $5 \%$ & $5 \%$ & $5 \%$ & $5 \%$ \\
\hline
\end{tabular}

Keterangan $: *=\%$ terhadap sari buah

\section{HASIL DAN PEMBAHASAN}

\section{Aktivitas Antioksidan}

Besarnya aktivitas antiosidan ditandai dengan besarnya nilai $\mathrm{IC}_{50}$, yaitu konsentrasi larutan sampel yang dibutuhkan untuk menghambat $50 \%$ radikal bebas DPPH. Semakin kecil nilai $\mathrm{IC}_{50}$ berarti semakin tinggi aktivitas antioksidannya. Secara spesifik suatu senyawa dikatakan sebagai antioksidan sangat kuat jika nilai $\mathrm{IC}_{50}$ kurang dari $50 \mathrm{ppm}$, kuat untuk $\mathrm{IC}_{50}$ bernilai $50-100$ ppm, sedang jika $\mathrm{IC}_{50}$ bernilai 100-150 ppm, dan lemah jika $\mathrm{IC}_{50}$ bernilai $150-200 \mathrm{ppm}$ [8].

Hasil anova menunjukkan bahwa lama fermentasi, konsentrasi gula, dan interaksi kedua perlakuan memberikan pengaruh nyata $(\mathrm{p}<0,05)$ terhadap aktivitas antioksidan. Hasil uji lanjut Tukey secara garis besar dapat dilihat pada Gambar 1.

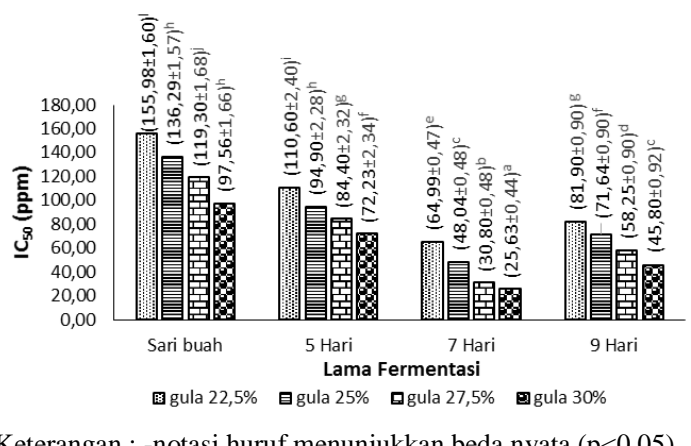

Gambar 1. Grafik aktivitas antioksidan cuka mangrove Sonneratia alba berdasarkan lama fermentasi dan konsentrasi gula.

Gambar 1 menunjukkan bahwa nilai $\mathrm{IC}_{50}$ menurun sampai lama fermentasi hari ke-7 dan mengalami peningkatan pada hari ke-9. Penambahan gula menyebabkan penurunan nilai $\mathrm{IC}_{50}$ dimana semakin banyak gula yang ditambahkan maka nilai $\mathrm{IC}_{50}$ cuka mangrove semakin menurun. Menurunnya nilai $\mathrm{IC}_{50}$ atau dapat disebut meningkatnya aktivitas antioksidan dipengaruhi oleh senyawa-senyawa fenolik dan asam organik [9]. Dalam proses fermentasi, senyawa fenolik dan asam-asam organik mudah terhidrolisa sehingga kelarutan senyawa fenolik dan asamasam organik di dalam cuka mangrove yang difermentasi akan meningkat dan menyebabkan aktivitas antioksidan meningkat. Adapun meningkatnya nilai $\mathrm{IC}_{50}$ atau menurunnya aktivitas antioksidan dapat disebabkan karena adanya penyusutan nutrisi yang dibutuhkan dalam pertumbuhan mikroba dan akan habis terkonsumsi oleh mikroba sehingga aktivitas antioksidan juga menurun. Total fenol dan vitamin $\mathrm{C}$ memiliki hubungan linier dengan aktivitas antioksidan, dimana semakin tinggi total fenol dan vitamin $\mathrm{C}$ maka 
aktivitas antioksidannya akan semakin tinggi ( $\mathrm{IC}_{50}$ semakin rendah). Hal ini disebabkan karena senyawa fenol dan vitamin $\mathrm{C}$ berperan sebagai antioksidan. Senyawa fenol merupakan komponen kimia yang berperngaruh terhadnap aktivitas antioksidan suatu bahan [10]. Sebagian besar antioksidan dalam bahan yang berasal dari tanaman merupakan senyawa fenol. Apabila kandungan senyawa fenol dalam sampel tinggi maka aktivitas antioksidannya juga tinggi [11,12]. Vitamin $\mathrm{C}$ juga berpengaruh terhadap tinggi rendahnya aktivitas antioksidan karena vitamin C merupakan salah satu senyawa yang berperan sebagai antioksidan dalam buah. Namun kontribusi vitamin $\mathrm{C}$ dalam aktivitas antioksidan tidak begitu tinggi. Kontribusi vitamin $\mathrm{C}$ terhadap aktivitas antioksidan sebesar 24\% [13]. Vitamin C sebagai antioksidan dapat memberikan satu atau dua elektronnya untuk menstabilkan radikal bebas [11].

Nilai $\mathrm{IC}_{50}$ terendah terdapat pada perlakuan hari ke-7 dengan konsentrasi gula $30 \%$ yaitu sebesar $25.63 \mathrm{ppm}$, sedangkan nilai $\mathrm{IC}_{50}$ terbesar didapat pada perlakuan lama fermentasi hari ke-5 dengan konsentrasi $22,5 \%$ yaitu sebesar 110,60 ppm. Hasil ini lebih tinggi dari cuka berbasis buah anggur Bali yang memiliki nilai $\mathrm{IC}_{50}$ sebesar 25.05 ppm [14]. Cuka salak dari berbagai varietas memiliki nilai $\mathrm{IC}_{50}$ sebesar $28,53 \mathrm{ppm}$ [15], sedang nilai $\mathrm{IC}_{50}$ pada sari buah mangrove Sonneratia alba yaitu sebesar 97,56-155,98 ppm.

\section{Total Fenol}

Senyawa fenol merupakan kelompok metabolit sekunder yang dapat ditemukan dalam jaringan tanaman [16]. Metabolit sekunder yang terdapat dalam buah mangrove Sonneratia alba meliputi alkaloid, flavonoid, fenolik, tannin dan steroid [4]. Pada penetapan kadar total fenol ditentukan dengan cara mengukur serapan yang merupakan hasil reagen Folin-Ciocalteu dengan sampel, menggunakan persamaan regresi linier dari kurva kalibrasi asam galat [17].

Hasil anova menunjukkan bahwa lama fermentasi, konsentrasi gula, dan interaksi keduannya memberikan pengaruh nyata $(\mathrm{p}<0,05)$ terhadap total fenol. Hasil uji lanjut Tukey secara garis besar dapat dilihat pada Gambar 2.

Gambar 2 menunjukkan bahwa kandungan fenol meningkat sampai lama fermentasi hari ke-7 dan mengalami penurunan pada hari ke-9 namun lebih tinggi daripada hari ke-5. Penambahan gula menyebabkan peningkatan total fenol dimana semakin banyak gula yang ditambahkan maka total fenol cuka mangrove akan semakin meningkat. Hal ini dapat disebabkan karena semakin banyak gula maka akan semakin banyak pula kandungan asam organiknya yang secara tidak langsung akan meningkatkan total fenol. Suasana asam dapat menyebabkan terjadinya peningkatan kadar fenolik [18]. Pada lama fermentasi hari ke-5 hingga hari ke-7 terjadi peningkatan total fenol, sedangkan pada hari ke-9 terjadi penurunan total fenol. Peningkatan total fenol diduga karena melibatkan bakteri dan khamir yang dapat bermetabolisme menghasilkan senyawa fenol melalui reaksi enzimatis [12].

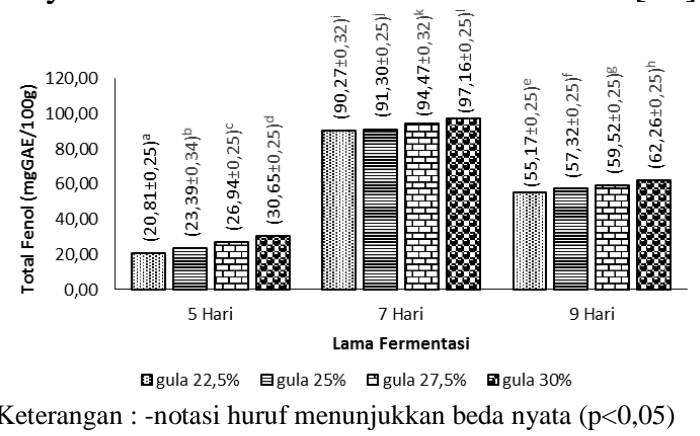

Gambar 2. Grafik total fenol cuka mangrove Sonneratia alba berdasarkan lama fermentasi dan konsentrasi gula.

Dalam proses fermentasi, senyawa fenolik dan asam-asam organik mudah terhidrolisis sehingga kelarutan fenolik dan asam-asam organik didalam cuka mangrove yang difermentasi akan meningkat. [9]. Penurunan total fenol diduga karena suasana asam menurun pada hari ke-9 sehingga menyebabkan menurunnya total fenol. Bakteri Acetobakter aceti hanya mampu menghasilkan asam asetat secara maksimal hingga hari ke-7 saja [6].

Total fenol terendah didapat pada lama fermentasi hari ke-5 dengan konsentrasi 
gula $22,5 \%$ yaitu sebesar 20,81 mgGAE/100g dan tertinggi pada lama fermentasi hari ke-7 dengan konsentrasi gula 30\% yaitu sebesar $97,16 \mathrm{mgGAE} / 100 \mathrm{~g}$. Hasil ini lebih rendah dari cuka berbasis buah anggur Bali yang memiliki kandungan total fenol sebesar 276,03 mgGAE/100g [14]. Cuka salak dari berbagai varietas memiliki kadar total fenol yaitu sebesar $111 \mathrm{mgGAE} / 100 \mathrm{~g}$ [15].

\section{Kadar Vitamin C}

Vitamin $\mathrm{C}$ dapat dimanfaatkan sebagai antioksidan yang dapat ditemukan dalam sayuran dan buah-buahan [19]. Penentuan kadar vitamin $\mathrm{C}$ pada minuman dapat ditentukan dengan metode spektrofotometri melalui oksidasi asam askorbat menjadi dehydroascorbic acid diitrofenilhidrazin (DNPH) dan diukur absorbansinya pada panjang gelombang 521 nm [20].

Hasil anova menunjukkan bahwa lama fermentasi, konsentrasi gula, dan interaksi kedua perlakuan memberikan pengaruh nyata $(\mathrm{p}<0,05)$ terhadap kadar vitamin C. Hasil uji lanjut Tukey secara garis besar dapat dilihat pada Gambar 3.

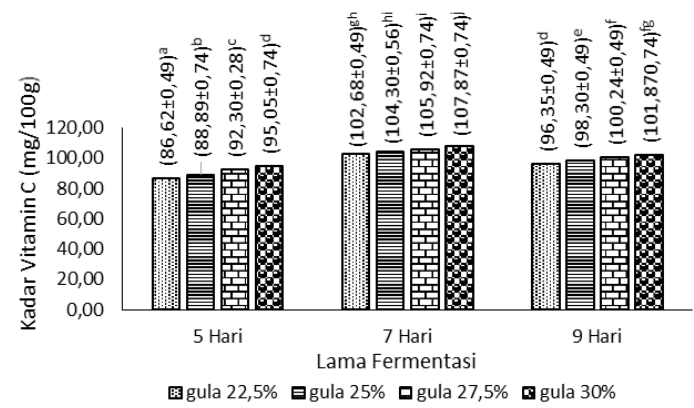

Keterangan : -notasi huruf menunjukkan beda nyata $(\mathrm{p}<0,05)$

Gambar 3. Grafik kadar vitamin C cuka mangrove Sonneratia alba berdasarkan lama fermentasi dan konsentrasi gula.

Gambar 3 menunjukkan bahwa kandungan Vitamin C meningkat sampai lama fermentasi hari ke-7 dan mengalami penurunan pada hari ke-9 namun lebih tinggi daripada hari ke-5. Penambahan gula menyebabkan peningkatan kadar vitamin $\mathrm{C}$ dimana semakin banyak gula yang ditambahkan maka kadar vitamin $\mathrm{C}$ cuka mangrove akan semakin meningkat. Adanya gula dan air pada cuka mangrove dapat menghambat oksidasi vitamin C [21]. Lama fermentasi mempengaruhi kadar vitamin $\mathrm{C}$ $[22,23,24]$. Hal ini disebabkan karena pada proses fermentasi bakteri Acetobacter akan menghasilkan vitamin C. D-Glukosa akan direduksi menjadi D-sorbitol. Pada tahap awal fermentasi, senyawa D-sorbitol akan berubah bentuk menjadi L-sorbosa dengan adanya enzim yang dihasilkan oleh bakteri Acetobacter. Gugus alkohol dari senyawasenyawa gula dapat dioksidasi oleh bakteri dengan adanya oksigen. L-sorbosa difermentasi lebih lanjut menjadi asam askorbat (Vitamin C), sehingga kadar vitamin C pun menjadi meningkat [23,24]. Seiring bertambahnya waktu fermentasi maka akan semakin banyak juga glukosa yang akan dirubah menjadi vitamin C [25]. Meningkatnya kadar vitamin $\mathrm{C}$ juga dapat dilihat dari hubungan lama fermentasi terhadap kandungan asam pada cuka. Salah satu asam organik yang dihasilkan dalam fermentasi adalah asam askorbat (vitamin C) [26]. Dengan demikian seiring tingginya kandungan asam pada hari ke-5 hingga hari ke-7 maka kadar vitamin $\mathrm{C}$ pun ikut meningkat. Penurunan kadar vitamin $\mathrm{C}$ pada hari ke-9 terkait dengan semakin lama fermentasi berlangsung, maka semakin habis kandungan gula [27]. Hal ini menyebabkan kandungan vitamin $\mathrm{C}$ menurun setelah didapatkan titik optimum, dikarenakan mikroorganisme sudah kehabisan makanan.

Kadar vitamin $\mathrm{C}$ terendah terdapat pada perlakuan lama fermentasi hari ke-5 dengan konsentrasi gula $22,5 \%$ yaitu sebesar $86,62 \mathrm{mg} / 100 \mathrm{~g}$ dan kadar vitamin $\mathrm{C}$ tertinggi didapat dari perlakuan lama fermentasi hari ke-7 dengan konsentrasi gula 30\% yaitu sebesar 107,87 mg/100g. Hasil ini lebih tinggi bila dibandingkan dengan cuka apel dengan penambahan wortel yang memiliki kandungan vitamin $C$ sebesar 4,05 mg/100g [28]. Cuka apel yang beredar di pasaran memiliki kandungan vitamin $\mathrm{C}$ sebesar 13,706 mg/100g [29]. Adapun kadar vitamin $\mathrm{C}$ buah mangrove pedada sebesar $56,74 \mathrm{mg} / 100 \mathrm{~g}$ [21]. 


\section{pH Cuka Pedada}

pH merupakan derajat keasaman yang digunakan untuk menyatakan tingkat keasaman atau kebasaan pada suatu larutan [30]. Derajat keasaman atau $\mathrm{pH}$ merupakan salah satu faktor penting dalam proses fermentasi karena mempengaruhi pertumbuhan mikroorganisme dan pembentukan produk pada saat fermentasi [31].

Hasil anova menunjukkan bahwa lama fermentasi, konsentrasi gula, dan interaksi kedua perlakuan memberikan pengaruh nyata $(\mathrm{p}<0,05)$. Hasil uji lanjut Tukey secara garis besar dapat dilihat pada Gambar 4.

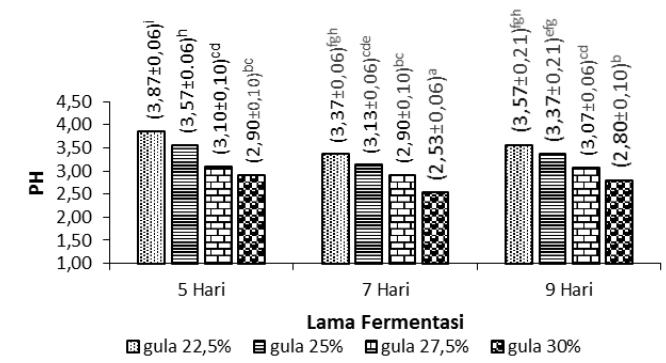

Keterangan : -notasi huruf menunjukkan beda nyata $(\mathrm{p}<0,05$

Gambar 4. Grafik pH cuka mangrove Sonneratia alba berdasarkan lama fermentasi dan konsentrasi gula.

Gambar 4 menunjukkan bahwa $\mathrm{pH}$ menurun pada lama fermentasi hari ke-7 dan mengalami kenaikan pada hari ke-9 namun lebih rendah dari $\mathrm{pH}$ hari ke-5. Penambahan gula menyebabkan penurunan $\mathrm{pH}$ dimana semakin banak gula yang ditambahkan maka $\mathrm{pH}$ cuka mangrove akan semakin rendah. Hal ini disebabkan karena bakteri dan yeast mengubah sukrosa menjadi asam organik sehingga dengan meningkatnya asam organik akan menurunkan nilai $\mathrm{pH}$ [32]. Seiring meningkatnya asam organik maka nilai $\mathrm{pH}$ akan menurun. Pada lama fermentasi hari ke-5 dan ke-7 pH mengalami penurunan karena pada hari tersebut bakteri Acetobacter aceti masih mampu mengubah alkohol menjadi asam asetat secara maksimal, sehingga menyebabkan nilai $\mathrm{pH}$ menurun. Kemudian pada hari ke-9 pH menjadi naik karena bakteri Acetobacter aceti sudah tidak mampu lagi menguraikan alkohol menjadi asam asetat.
Waktu optimum bakteri Acetobacter aceti untuk merubah alkohol menjadi asam asetat adalah pada hari ke-7, Setelah itu maka bakteri Acetobakter aceti sudah tidak mampu menguraikannya secara maksimal [6].

Nilai $\mathrm{pH}$ terendah didapatkan pada perlakuan lama fermentasi hari ke-7 dengan penambahan gula 30\% yaitu sebesar 2,53. Hasil penelitian ini lebih rendah dibandingkan nilai $\mathrm{pH}$ cuka anggur Bali yang mempunyai nilai $\mathrm{pH}$ 3,54 [14 dan cuka salak mempunyai nilai $\mathrm{pH} 2,71$ [15].

\section{Asam Asetat}

Asam asetat atau asam cuka merupakan senyawa organik yang mengandung gugus asam karboksilat, yang biasa digunakan sebagai pemberi rasa dan aroma dalam makanan. Asam asetat dihasilkan dari fermentasi dengan cara mengubah alkohol menjadi asam asetat oleh mikroorganisme [33].

Hasil anova menunjukkan bahwa lama fermentasi, konsentrasi gula, dan interaksi kedua perlakuan memberikan pengaruh nyata $(\mathrm{p}<0,05)$ terhadap asam asetat. Hasil uji lanjut Tukey secara garis besar dapat dilihat pada Gambar 5.

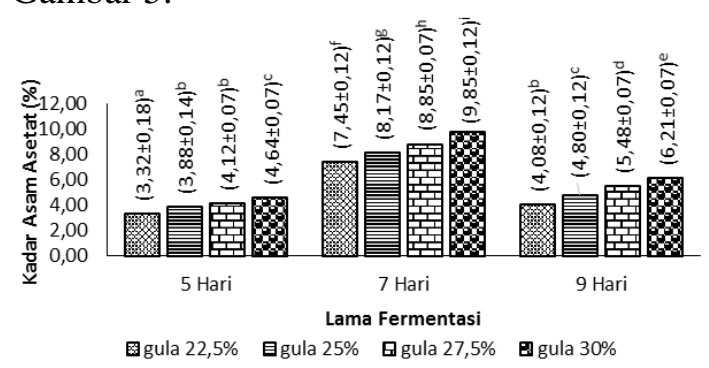

Keterangan : -notasi huruf menunjukkan beda nyata $(\mathrm{p}<0,05$

Gambar 5. Grafik asam asetat cuka mangrove Sonneratia alba berdasarkan lama fermentasi dan konsentrasi gula.

Gambar 5 menunjukkan bahwa kadar asam asetat meningkat pada lama fermentasi hari ke-7 dan mengalami penurunan pada hari ke-9 namun lebih tinggi dari kadar asam asetat hari ke-5. Penambahan gula menyebabkan peningkatan asam asetat dimana semakin banyak gula yang ditambahkan maka kadar asam asetat cuka mangrove akan semakin meningkat. Hal ini 
disebabkan karena sukrosa akan dirombak menjadi glukosa dan fruktosa oleh bakteri dan khamir. Glukosa digunakan untuk membentuk alkohol dan asam-asam organik seperti asam asetat dan asam glukonat, sehingga kandungan asam asetat pun meningkat [12]. Pada lama fermentasi hari ke-5 hingga hari ke-7 terjadi peningkatan asam asetat, sedangkan pada hari ke-9 terjadi penurunan asam asetat. Hal ini disebabkan karena pada hari ke-5 hingga hari ke-7 bakteri Acetobacter aceti masih mampu merombak alkohol menjadi asam asetat secara maksimal. Waktu optimum bakteri Acetobacter aceti untuk merombak alkohol menjadi asam asetat yaitu pada hari ke-7 [6]. Sehingga hal ini dapat menyebabkan penurunan asam asetat pada hari ke-9.

Kadar asam asetat terendah didapat pada lama fermentasi hari ke-5 dengan penambahan gula $22,5 \%$ yaitu sebesar $3,32 \%$ dan kadar asam asetat tertinggi didapat pada lama fermentasi hari ke-7 dengan penambahan gula sebesar 30\% yaitu sebesar $9,85 \%$. Hasil ini lebih tinggi dibandingan cuka pengolahan limbah salak Jawa yaitu 3,26\% [34]. Kadar asam asetat cuka buah anggur Bali 2,58\% [14]. Berdasarkan SNI 01-43711996 tentang standar mutu cuka, syarat kadar asam asetat pada cuka yaitu minimal adalah $4 \%$, sehingga kadar asam asetat pada cuka mangrove Sonneratia alba dapat dikatakan telah memenuhi standar kecuali pada perlakuan lama fermentasi 5 hari dengan konsentrasi gula 22,5\% dan 25\% dengan kadar asam asetat masing-masing yaitu 3,26\% dan $3,88 \%$.

\section{KESIMPULAN}

Lama fermentasi dan penambahan gula memberikan pengaruh terhadap kadar alkohol, asam asetat, total fenol, vitamin $\mathrm{C}$ dan aktivitas antioksidan dari sari buah mangrove Sonneratia alba tanpa kulit.

Cuka buah Soneratia alba yang memenuhi SNI dan beraktivitas antioksidan tinggi adalah perlakuan lama fermentasi hari ke-7 dan penambahan kadar gula $25 \%$ dengan nilai aktivitas antioksidan $\mathrm{IC}_{50} 48,04 \mathrm{ppm}$, asam asetat $8,17 \%$, alkohol $6,44 \%$, nilai $\mathrm{pH}$
3,13, total fenol $91,3 \mathrm{mgGAE} / 100 \mathrm{~g}$, dan vitamin C 104,3 mg/100g.

\section{UCAPAN TERIMA KASIH}

Terima kasih kepada Fakultas Perikanan dan Ilmu Kelautan Universitas Brawijaya yang telah memberikan bantuan dana untuk pembiayaan penelitian melalui BPP FPIK UB tahun 2018.

\section{DAFTAR PUSTAKA}

[1] H. Purnobasuki, "Potensi mangrove sebagai tanaman obat," BIOTA, vol. 11, no. 2, hal. 125-126, 2004.

[2] N. H. Puspayanti, H. T. T. Andi, M.S. Samsurizal, "Jenis-jenis tumbuhan mangrove di Desa Lebo Kecamatan Parigi Kabupaten Parigi Moutong dan pengembangannya sebagai media pembelajaran," e-Jipbiol, vol. 1, no. 1, hal. 1-9, 2013.

[3] R. D. E. Manalu, "Kadar.beberapa vitamin pada buah pedada (Sonneratia caseolaris) dan hasil olahannya"" Skripsi. Departemen Teknologi Hasil Perairan, Institut Pertanian Bogor, hal. 3, 2011.

[4] Z. Paputungan, W. Djuhria, E.K. Bertie, "Uji fitokimia dan aktifitas antioksidan buah mangrove Sonneratia alba di desa Nunuk Kecamatan Pinolosian Kabupaten Bolaang Mongondow Selatan," Jurnal Media Teknologi Hasil Perikanan, vol. 5, no. 3, hal. 190-195, 2017.

[5] H. Pujisiswanto, "Pengaruh fermentasi limbah cair pulp kakao terhadap tingkat keracunan dan pertbuhan beberapa gulma berdaun lebar," Jurnal Penelitian Pertanian Terapan, vol. 12, no. 1, hal. 1319, 2012.

[6] A.A. Januaresti, T. S. Ela, T. Yusman, Pengaruh konsentrasi inoculum Acetobacter aceti dan lama fermentasi terhadap karakteristik vinegar murbei (Morus alba)," Jurusan Teknologi Pangan. Bandung, Universitas Pasundan, hal. 1-11, 2016.

[7] D. Caturryanti, L. Sri, dan T. Siti, "Pengaruh varietas apel dan campuran 
bakteri asam asetat terhadap proses fermentasi cider," AGRITECH, vol. 28, no. 2, hal. 70-75, 2008

[8] S.G. Dungir, G.K. Dewa, S.K. Vanda, "Aktivitas aktioksidan ekstrak fenolik dari kulit buah manggis (Garcinia mangostana L.)," JURNAL MIPA UNSRAT ONLINE, vol. 1, no. 1, hal. 11-15, 2012.

[9] L. Dewi, P. H. Susanti, L.S. Agustian, "Aktivitas antioksidan, kadar fenol total, dan kadar Kafein pada fermentasi kombu kopi robusta dalam berbagai konsentrasi gula," Makalah Seminar Nasional Mikrobiologi. Fakultas biologi UKSW, hal. 137-147, 2014.

[10] N. L. D. Rupadani, N. M. P. Susanti, N. P. E. Leliqia, "Uji aktivitas antioksidan minuman kombucha lokal di Bali dengan substrat gambir", Jurnal Farmasi Udayana, vol. 3, no. 2, hal 100-104, 2013.

[11] H. Matheos, R.J.R. Max, dan S. Sri, "Aktivitas antioksidan dari ekstrak daun kayu bulan (Pisonia alba)," PHARMACON vol. 3 , no. 3 , hal. 235246, 2014.

[12] P.S. Suhardini, dan Z. Elok, "Studi aktivitas antioksidan kombucha dari berbagai jenis daun selama fermentasi". Jurnal Pangan dan Agroindustri, vol. 4, no. 1, hal 221-229, 2016.

[13] K. Aaby, D. Ekeberg, dan G. Skrede, "Characterization of phenolik compounds in strawberry (Fragaria $x$ ananasa) fruit by different HPLC detector and contribution of individual compound to total antioksidan capasity," J. Agric Food Chem., vol. 55, no. 11, hal. 4395-4408, 2007.

[14] Z. Elok, dan V. Christina, "Studi aktivitas antioksidan cuka berbasis buah anggur Bali (Vitis vinifera) utuh dan tanpa kulit," Jurnal Teknologi Hasil Pertanian, vol. 7, no. 2, hal. 95-103, 2014.

[15] Z. Elok, Austin, H.S. Feronika, Studi aktivitas antioksidan cuka salak dari berbagai varietas buah salak (Salacca zalacca). Jurnal Teknologi Pertanian," vol. 16, no. 2, hal. 89-96, 2015.
[16] A. Redha, "Flavonoid: struktur, sifat antioksidatif dan peranannya dalam sifat biologis," Jurnal Berlian, vol. 9, no. 2, hal. 196-202, 2010.

[17] M.R. Marjoni, Afrinaldi, D.N. Ari, "Kandungan total fenol dan aktivitas antioksidan ekstrak air daun kersen (Muntingina calabura L.)," Jurnal Kedokteran Yarsi, vol. 23, no. 3, hal. 187-196, 2015.

[18] R. Jayabalan, P. Subatradevi, S. Marimuthu, M. Sathiskumar, K. Swaminathan, "Changes in free-radical scavenging ability of combucha tea during fermentation," Food Chemistry, Vol. 109, no. 1, hal. 227-234, 2008.

[19] D. Iriani, dan P. Nugraheni, "Kandungan klorofil, karatenoid, dan vitamin C beberapa jenis sayuran daun pada pertanian periurban di Kota Surabaya," Jurnal Matematika, Sains, dan Teknologi, vol. 15, no. 2, hal. 84-90, 2014.

[20] E.T. Damayanti, dan K. Puji, "Perbandingan metode penentuan vitamin C pada minuman kemasan menggunakan metode spektrootometer UV-VIS DAN Iodimetri," Prosiding Seminar Nasional Kimia dan Pembelajarannya. Jurusan Kimia FMIPA UM, hal. 258-266, 2017.

[21] R. D. E. Manalu, S. Ella, R. Fifi, K. Nia, "Kandungan zat gizi makro dan vitamin buah pedada (Sonneratia caseolaris," Penelitian Gizi dan Makanan, vol. 36, no. 2, hal. 135-140, 2013.

[22] I. Falahudin, I. Aprianti, dan Nurfadhilah, "Pengaruh proses fermenatasi daun sirsak (Anonnna muricata $L$.) terhadap kadar vitamin C," Jurnal Biota, vol. 3, no. 2, hal. 90-95, 2017.

[23] P.P. Thorat, S.K. Sadawarte, A.R. Sawate, G. M. Machewad, "Studies on efect of fermentation on physichemical propherties of vegetables and preparation of sauce". International Journal of Current Mikrobiology and Applied Sciences, vol. 6, no. 8, hal. 3537-3545, 2017. 
[24] F.O. Adetuyi, dan T.A. Ibrahim, "Effect of fermentation time on the phenolic, flavonoid and Vitamin C Contents and antioxidant activities of ocra (Abelmoschus esculentus) seeds," Nigerian Food Journal, vol. 32, no. 2, hal. 128-137, 2014.

[25] Haryanto, L. T. 2018. Pengaruh lama fermentasi terhadap kandungan vitamin $\mathrm{C}$ dan perbandingan aktivitas antioksidan kombucha teh bunga sepatu merah (Hibiscus rosa-inensis L.) dengan teh bunga sepatu pink (Hibiscus rosasinensis $c v$ natal). Skripsi. Jurusan Pendidikan Matematika dan Ilmu Pengetahuan alam. Yogyakarta: Universitas Sanata Dharma. $54 \mathrm{hlm}$.

[26] F.A. Pratiwi, A.A. P. Agung, M. Sri, "The characteristic of coffee powder quality in trheatment fermentation time and temperatur in medium combucha tea," Jurnal REKAYASA DAN MANAJEMEN AGROINDUSTRI, vol. 3, no. 1, hal. 1-10, 2015.

[27] Y. Puspitasari, P. Retno, N. Maulina, "Analisis kandungan vitamin $\mathrm{C}$ teh kombucha berdasarkan lama fermentasi sebagai alternatif minuman untuk antioksidan," GLOBAL HEALTH SCIENCE, vol 2, no. 3, hal. 245-253, 2017.

[28] A.Z. Arifin, dan H.P. Sri, "Pengaruh penambahan wortel (Daucus carota) pada pembuatan cuka apel terhadap kualitas minuman hasil fermentasi," Jurnal Teknologi Pangan, vol. 9, no. 1, hal. 34-40, 2018.

[29] N. Rahmawati, Sugiyanta, dan N. S. Eli, "Pengaruh pemberian cuka apel "A" terhadap kadar MDA hepar tikus wistar jantan yang diinduksi paraSetamol dosis toksik," E-Jurnal Pustaka Kesehatan, vol. 6, no. 2, hal. 272-277, 2018.

[30] E. Ihsanto, dan H. Sadri, "Rancang bangun sistem pengukuran $\mathrm{pH}$ meter dengan menggunakan mikrokontroller arduino uno," Jurnal Teknologi Elektro, vol. 5, no. 3, hal. 130-137, 2014.

[31] U. Fadilah, I. M. W. Made, N.A. Semadi, "Studi pengaruh $\mathrm{pH}$ awal media dan lama fermentasi pada proses produksi etanol dari hidrolisat tepung biji nangka dengan menggunakan Saccharomyces cerevisiae," Jurnal Rekayasa dan Manajemen Agroindustri, vol. 6, no. 2, hal. 92-102, 2018.

[32] W. Duwi, dan W. Elok, "Karakteristik kimiawi dan mikrbiologis kombucha dari berbagai daun tinggi fenol selama fermentasi.," Jurnal Pangan dan Agroindustri, vol. 3, no. 4, hal. 14461457, 2015.

[33] Wusnah, Meriatna, L. Rina, "Pembuatan asam asetat dari cucian kopi robusta dan arabika dengan proses fermentasi". Jurnal Teknologi Kimia Unimal, Vol 7 no 1, hal. 61-72, 2018.

[34] D. Erlita, "Pengolahan limbah buah salak jawa (Sallaca edulis) sebagai vinegar dalam upaya pengelolaan lingkungan," Jurnal Rekayasa Lingkungan, vol. 16, no. 2, hal. 1-10, 2016. 